UNIVERSIDAD DEL CEMA

Buenos Aires

Argentina

Serie

DOCUMENTOS DE TRABAJO

Área: Finanzas

\title{
A MODEL FREE APPROACH TO THE PRICING OF DOWNSIDE RISK IN ARGENTINEAN STOCKS
}

José P. Dapena, Juan A. Serur y Julián R. Siri

Noviembre 2019

Nro. 703

https://ucema.edu.ar/publicaciones/doc_trabajo.php UCEMA: Av. Córdoba 374, C1054AAP Buenos Aires, Argentina

ISSN 1668-4575 (impreso), ISSN 1668-4583 (en línea)

Editor: Jorge M. Streb; asistente editorial: Valeria Dowding <jae@cema.edu.ar> 



\title{
A MODEL FREE APPROACH TO THE PRICING OF DOWNSIDE RISK IN ARGENTINEAN STOCKS
}

\author{
José P. Dapena, Juan A. Serur and Julián R. Siri* \\ UNIVERSIDAD DEL CEMA
}

\begin{abstract}
The return dynamics of Argentina's main stock index, the SP Mer.Val., show a high level of volatility, signaling a higher degree of downside risk. To hedge against that specific risk, investors could buy put options. However, the Argentinean capital markets lacks variety of hedging contracts. The basic availability of put options depends on the possibility of short selling the underlying security, i.e. transfer risk to a third party, something not properly developed in the domestic market. Since data processing power has geometrically increased in the last decades and some mathematic formulas that were helpful for calculation had been surpassed by data gathering and processing that helps to find a better estimate when necessary, in this paper we show the point calculating protection against downside risk in the Argentinean stock market, using real data and programming an algorithm to perform calculations instead of resorting the standard Black-Scholes-Merton formulae, by means of a model free approach to acknowledge the issue.
\end{abstract}

JEL Classification: C1, C3, N2, G11

Keywords: Asset pricing, options pricing, insurance, capital markets

\footnotetext{
* José P. Dapena, Dr.Econ., is the Director of the Department of Finance at University of CEMA. Email: jd@ucema.edu.ar. Juan A. Serur, M.Fin., is an Assistant Professor at University of CEMA. Email: juanandresserur@gmail.com. Julián R. Siri, MSc. in Financial Engineering, is a Professor at University of CEMA. Email: jrs06@ucema.edu.ar The author's views are on their own and do not necessarily represent those of the Universidad del CEMA.

We deeply thank comments of participants from XXXVIII Jornadas de la Sociedad Argentina de Docentes en Administración Financiera (SADAF), LIII Reunión Anual de la Asociación Argentina de Economía Política (AAEP) and VII Congreso de Matemática Aplicada, Computacional e Industrial (MACI).
} 


\section{Introduction}

Option contracts are contingent contracts that can be associated to insurance, so selling options is equivalent to selling insurance. Option buyers buy them looking for insurance or speculation. In any case, an underlying risk is transferred and an appropriate price is place in order to both parties agree. The main point is at which price the risk is transferred from one side to the other.

Even though there have been along the history heuristics on how to calculate the pricing of options, in 1973 Merton, Black and Scholes established under certain assumptions a closed formula to calculate the value of european options, which awarded two of them the Nobel Prize (Black died before the award). The development relied on a risk neutral world using risk neutral probabilities instead of the true probabilities of events, which highly simplified the calculations.

However, the development relied on the need of complete markets, i.e. insurances is offered for any state of the nature; or alternatively, the law of one priced holds, i.e. non arbitrage opportunities exist. A put option is a contract that gives its owner the right, but not the obligation, to sell a specified amount of an underlying security at a specified price, within a specified time frame.

This is the opposite of a call option, which gives the holder the right to buy an underlying security at a specified price, before the option expires. The seller of the option has the obligation to buy (or sell) the underlying asset ate the specified price if the option's buyer exercises her right. The put option protects the holder against a downside movement of the price of the underlying security. The seller of the put option is selling insurance against that risk. At maturity, the put option may end up in the money -the event being insured happens- or it might end up at the money or out of the money, and the option expires worthless. The theory of option pricing $^{1}$ relies on the existence of complete capital markets, giving the chance to construct replicating portfolios and hence providing a fair value for contracts insuring to the same risk.

The point that option contracts can be associated to insurance s well developed in the literature (Dapena Siri 2015). For instance a car-insurance buyer pays a premium every month to an insurance company, to protect her vehicle. It could be the case that the car is neither stolen nor it suffers an accident (the policy expires "out of the money"), and the insurance company keeps the premium originally received, turned into a profit. However, if the owner does happen to be involved in an accident, the insurance company pays her the amount insured (the policy ends up in the money). Premiums charged by insurance companies try to be aligned with the likelihood of having an accident, and companies must maintain a certain amount of money (a guarantee fund or actuarial reserves) to pay out whenever accidents occur.

Much of the profit in the insurance industry comes on one hand, from a quantitative process of trying to avoid ensuring drivers that are prone to accidents or leave their cars unsafe, or alternatively charge them with higher premiums; and on the other hand, from financial investments made with the premiums collected and kept as guarantee fund.

\footnotetext{
${ }^{1}$ Black and Scholes (1973), Merton (1973).
} 
In our work we want to explore the equities downside risk in Argentinean stock market, from the perspective of an insurance broker; this in turns means that the insurer, to provide hedge against downside risk, intends to calculate profit (premiums) and losses (payment of events) that break even the economic equation. The purpose is to calculate (at the minimum), how much premium on average (as a percentage of the price of the underlying) the insurer must charge to give protection against that risk, given the observed pattern of historical returns. The paper is organized as follows: in section II we depict the dynamics of downside risk in stock prices for Argentina's capital market, and the availability of contracts to hedge against it; in section III we introduce the basics of an alternative model to calculate a fair price of downside risk protection, given a self-insurance approach, and the results; finally in the last section we discuss the conclusions.

\section{Downside risk in the Argentinean stock market}

The following graph shows the dynamics of the Argentinean main stock index, the Mer.Val. index -\$MERV-, for the period between January 2003 and June 2018. ${ }^{2}$

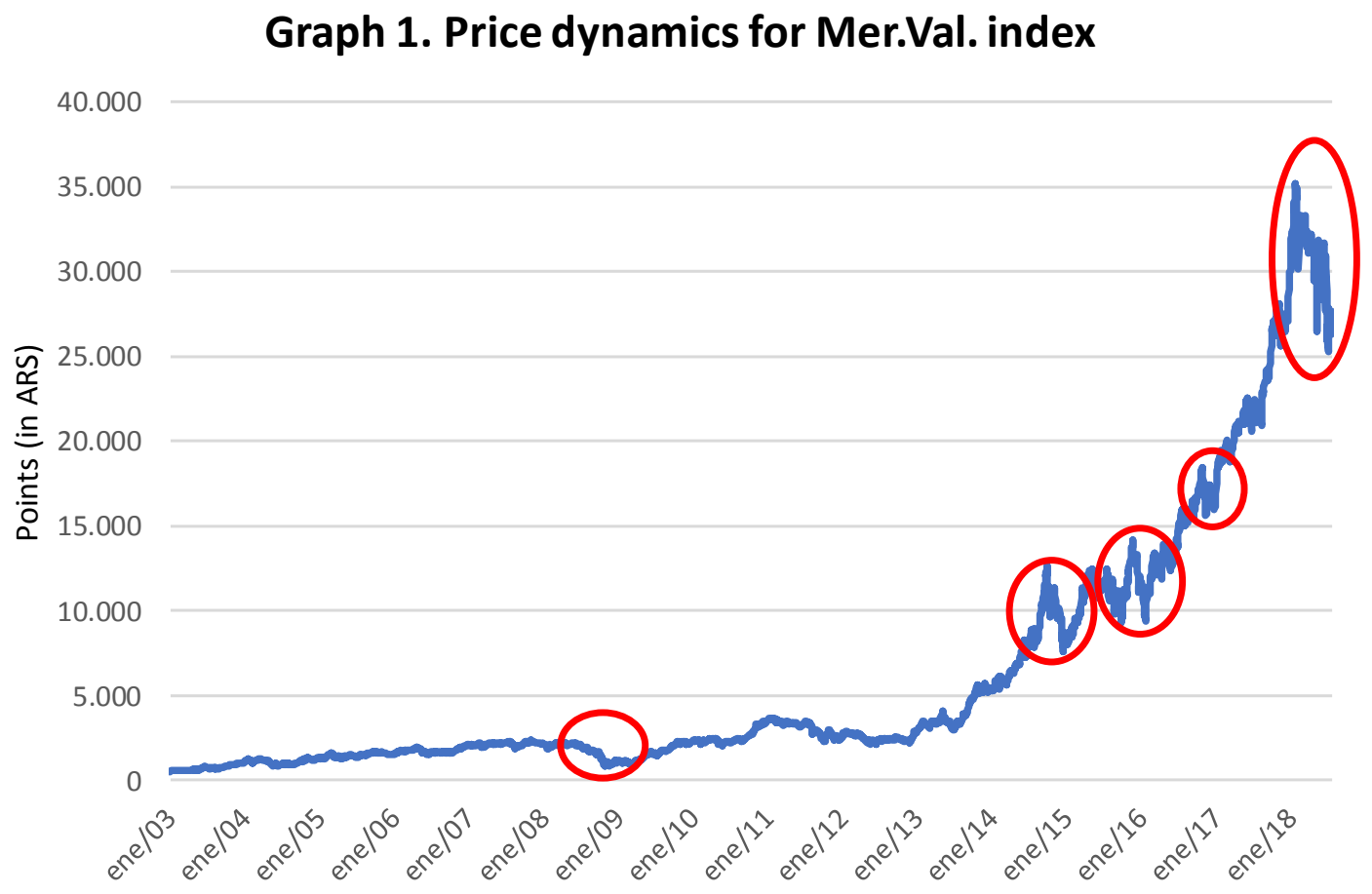

Though we find a positive drift (the average annual compound rate of return is $25 \%$ ), it can be mainly explained by the inflation component (the annual rate of inflation accounted for an average of $21 \%$ in the same period).

However, we are not so concerned about the rate of return but more about the underlying risk. As we can see from a visual inspection, though the drift is positive, there are periods of time

\footnotetext{
${ }^{2}$ Data retrieved from https://www.bolsar.com/Vistas/Herramientas/PaginaDescargaSeriesHistoricas.aspx.
} 
where the index experiences downward movements, some of them significant (see the red circles pointing some of those periods). So, downside risk is non-trivial in Argentinean stocks.

The following graph shows the histogram of daily returns, where we draw a line separating negative from positive daily returns:

\section{Graph 2. Mer.Val. index daily returns histogram}

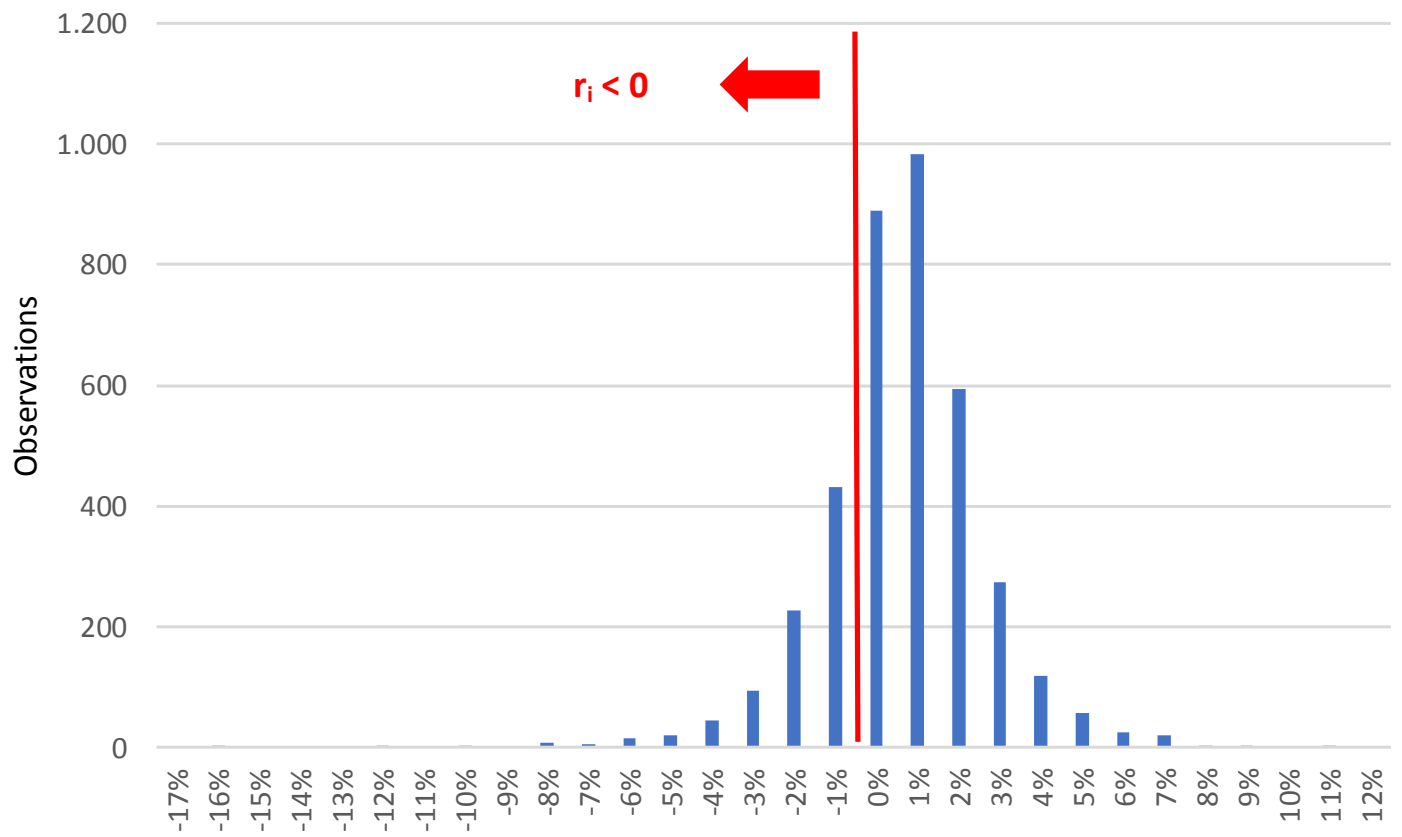

In the sample period, we find 3806 prices retrieved, giving rise to the calculation of 3805 daily returns. The following table shows the main statistics from the sample:

Table 1: Descriptive statistics of Mer.Val

\begin{tabular}{lr}
\hline Total Observations & 3805 \\
\hline Number of Positive returns & 2070 \\
\hline Number of Negative returns & 1735 \\
\hline Max Return & $11 \%$ \\
\hline Min Return & $-16 \%$ \\
\hline Standard Deviation (Annualized) & $32 \%$ \\
\hline Downside Deviation (Annualized) & $24 \%$ \\
\hline \hline
\end{tabular}

From the data we can see that, measured both in numbers and in standard deviation, downside risk is not trivial in Argentinean stock market, so having protection against downside movements in price may be valuable for investors.

As for this point, we have not found much variety of contracts allowing for such protection. In the main stock exchange (BYMA) we see the following list of options ${ }^{3}$ :

\footnotetext{
${ }^{3}$ Data from http://www.merval.sba.com.ar/Vistas/Cotizaciones/OpcionesSuscripcion.aspx as of 7/19/18
} 
Data 1

\begin{tabular}{|c|c|c|c|c|c|c|}
\hline Opción & $\begin{array}{c}\text { Hora } \\
\text { Cotización }\end{array}$ & $\begin{array}{c}\text { Cierre } \\
\text { Anterior }\end{array}$ & $\begin{array}{l}\text { Último } \\
\text { Precio }\end{array}$ & $\begin{array}{l}\text { Variación } \\
\text { Diaria }\end{array}$ & $\begin{array}{l}\text { Volumen } \\
\text { Efectivo en } \\
\text { Pesos }\end{array}$ & Lotes $(*)$ \\
\hline AGRC17.0AG & $13: 55: 06$ & 0,200 & 0,200 & $0,00 \%$ & $2.476,00$ & 100,00 \\
\hline ALUC13413G & $12: 13: 50$ & 8,900 & 7,500 & $-15,73 \%$ & 750,00 & 1,00 \\
\hline ALUC17213G & $14: 20: 31$ & 3,200 & 3,100 & $-3,13 \%$ & $25.895,00$ & 84,00 \\
\hline ALUC20.9AG & $14: 45: 10$ & 0,900 & 0,800 & $-11,11 \%$ & $6.000,00$ & 70,00 \\
\hline ALUC5.113G & 14:00:02 & 14,479 & 14,600 & $+0,84 \%$ & $73.000,00$ & 50,00 \\
\hline ALUC5.113O & 13:16:08 & 15,500 & 15,700 & $+1,29 \%$ & $1.512 .730,00$ & 968,00 \\
\hline ALUC5.80DI & $14: 42: 19$ & 16,500 & 15,100 & $-8,48 \%$ & $1.654 .300,00$ & $1.060,00$ \\
\hline BMAC196.AG & $12: 36: 27$ & 7,000 & 7,600 & $+8,57 \%$ & $4.540,00$ & 6,00 \\
\hline BYMC440.AG & $14: 22: 57$ & 5,100 & 3,950 & $-22,55 \%$ & $1.185,00$ & 3,00 \\
\hline CEPC35.3AG & 14:09:20 & 0,500 & 0,200 & $-60,00 \%$ & 200,00 & 10,00 \\
\hline COMC3.00AG & $13: 16: 53$ & 0,776 & 0,760 & $-2,06 \%$ & $32.680,00$ & 430,00 \\
\hline COMC3.75AG & $14: 07: 52$ & 0,160 & 0,142 & $-11,25 \%$ & $10.992,00$ & 720,00 \\
\hline COMC3.90AG & $13: 36: 02$ & 0,100 & 0,097 & $-3,00 \%$ & $10.680,00$ & $1.100,00$ \\
\hline COMC4.05AG & $14: 19: 57$ & 0,069 & 0,060 & $-13,04 \%$ & $22.786,00$ & $3.591,00$ \\
\hline COMC4.20AG & 14:04:02 & 0,040 & 0,040 & $0,00 \%$ & $1.952,00$ & 488,00 \\
\hline GFGC100.AG & $14: 44: 54$ & 6,438 & 5,900 & $-8,36 \%$ & $624.333,00$ & 970,00 \\
\hline GFGC100.OC & $14: 27: 59$ & 14,000 & 12,000 & $-14,29 \%$ & $2.400,00$ & 2,00 \\
\hline GFGC102.AG & $14: 41: 15$ & 5,545 & 4,900 & $-11,63 \%$ & $1.758 .153,00$ & $3.317,00$ \\
\hline GFGC105.AG & $14: 42: 23$ & 4,133 & 3,500 & $-15,32 \%$ & $435.000,00$ & $1.161,00$ \\
\hline GFGC108.AG & $14: 45: 07$ & 3,139 & 2,700 & $-13,99 \%$ & $448.686,00$ & $1.587,00$ \\
\hline GFGC111.AG & $14: 44: 31$ & 2,267 & 1,750 & $-22,81 \%$ & $336.331,00$ & $1.694,00$ \\
\hline GFGC117.AG & $14: 45: 10$ & 1,431 & 1,210 & $-15,44 \%$ & $64.624,00$ & 491,00 \\
\hline GFGC120.AG & $14: 32: 41$ & 1,101 & 0,900 & $-18,26 \%$ & $125.638,00$ & $1.253,00$ \\
\hline GFGC120.OC & $13: 46: 48$ & 6,220 & 5,900 & $-5,14 \%$ & $2.950,00$ & 5,00 \\
\hline GFGC123.AG & $14: 21: 12$ & 0,797 & 0,700 & $-12,17 \%$ & $20.161,00$ & 260,00 \\
\hline GFGC126.AG & $14: 13: 13$ & 0,558 & 0,550 & $-1,43 \%$ & $12.820,00$ & 234,00 \\
\hline GFGC12816G & $14: 46: 31$ & 0,500 & 0,450 & $-10,00 \%$ & $22.907,00$ & 525,00 \\
\hline GFGC129.OC & 11:08:18 & 4,000 & 3,250 & $-18,75 \%$ & $6.500,00$ & 20,00 \\
\hline GFGC132.AG & $14: 42: 55$ & 0,411 & 0,360 & $-12,41 \%$ & $6.080,00$ & 174,00 \\
\hline GFGC13716G & $14: 41: 46$ & 0,400 & 0,300 & $-25,00 \%$ & $14.750,00$ & 450,00 \\
\hline GFGC138.OC & $12: 12: 14$ & - & 1,900 & $0,00 \%$ & $3.800,00$ & 20,00 \\
\hline GFGC141.AG & 14:08:05 & 0,250 & 0,250 & $0,00 \%$ & $8.100,00$ & 320,00 \\
\hline GFGC144.AG & $14: 33: 29$ & 0,250 & 0,200 & $-20,00 \%$ & $32.857,00$ & $1.271,00$ \\
\hline GFGC162.OC & $13: 58: 48$ & 0,550 & 0,510 & $-7,27 \%$ & 51,00 & 1,00 \\
\hline GFGC165.AG & $14: 36: 27$ & 0,154 & 0,130 & $-15,58 \%$ & $9.075,00$ & 618,00 \\
\hline GFGC85.0AG & $13: 07: 30$ & 18,000 & 15,760 & $-12,44 \%$ & $58.490,00$ & 35,00 \\
\hline GFGC90.0AG & $14: 25: 53$ & 12,000 & 11,000 & $-8,33 \%$ & $114.460,00$ & 101,00 \\
\hline GFGC95.0AG & $14: 38: 22$ & 9,463 & 8,021 & $-15,24 \%$ & $86.590,00$ & 97,00 \\
\hline GFGV102.AG & $14: 35: 48$ & 5,760 & 7,300 & $+26,74 \%$ & $179.483,00$ & 270,00 \\
\hline GFGV59159G & $14: 19: 03$ & 0,200 & 0,240 & $+20,00 \%$ & $4.730,00$ & 230,00 \\
\hline GFGV85.0AG & $14: 16: 27$ & 1,170 & 1,000 & $-14,53 \%$ & $2.000,00$ & 20,00 \\
\hline GFGV85.0OC & $13: 12: 47$ & 2,200 & 2,000 & $-9,09 \%$ & $4.000,00$ & 20,00 \\
\hline GFGV90.0AG & $14: 46: 18$ & 2,000 & 2,200 & $+10,00 \%$ & $64.251,00$ & 307,00 \\
\hline GFGV95.0AG & $13: 02: 56$ & 3,250 & 3,600 & $+10,77 \%$ & 360,00 & 1,00 \\
\hline GVAC5.00AG & $13: 12: 18$ & 0,640 & 0,600 & $-6,25 \%$ & $6.000,00$ & 100,00 \\
\hline GVAC6.00AG & $14: 38: 45$ & 0,195 & 0,170 & $-12,82 \%$ & $16.681,00$ & 975,00 \\
\hline GVAC6.00OC & $14: 40: 19$ & 0,700 & 0,680 & $-2,86 \%$ & $3.680,00$ & 54,00 \\
\hline GVAV5.80AG & $14: 22: 27$ & 0,800 & 0,749 & $-6,38 \%$ & 300,00 & 4,00 \\
\hline METC25.0DI & $13: 16: 38$ & 13,500 & 13,500 & $0,00 \%$ & $1.350,00$ & 1,00 \\
\hline PAMC45.1AG & $14: 44: 05$ & 1,220 & 1,150 & $-5,74 \%$ & $1.150,00$ & 10,00 \\
\hline PAMC57.0AG & $13: 58: 55$ & 0,100 & 0,100 & $0,00 \%$ & $1.000,00$ & 100,00 \\
\hline PBRC112.AG & $14: 37: 33$ & 41,500 & 41,900 & $+0,96 \%$ & $41.900,00$ & 10,00 \\
\hline PBRC125.AG & $14: 27: 54$ & 28,046 & 28,440 & $+1,40 \%$ & $154.276,00$ & 55,00 \\
\hline PBRC135.AG & $14: 27: 57$ & 20,000 & 19,000 & $-5,00 \%$ & $58.730,00$ & 31,00 \\
\hline PBRC13966G & $14: 38: 47$ & 16,000 & 16,450 & $+2,81 \%$ & $57.195,00$ & 36,00 \\
\hline PBRC145.AG & $12: 51: 52$ & 12,500 & 11,900 & $-4,80 \%$ & $11.900,00$ & 10,00 \\
\hline PBRC150.AG & $14: 40: 36$ & 9,323 & 9,900 & $+6,19 \%$ & $637.013,00$ & 707,00 \\
\hline PBRC150.OC & $13: 55: 38$ & 20,000 & 16,000 & $-20,00 \%$ & $3.200,00$ & 2,00 \\
\hline PBRC155.AG & 14:34:06 & 7,012 & 7,200 & $+2,68 \%$ & $450.305,00$ & 658,00 \\
\hline
\end{tabular}




\begin{tabular}{ccccccc} 
PBRC15966G & $14: 43: 53$ & 4,893 & 5,200 & $+6,27 \%$ & $744.664,00$ & $1.563,00$ \\
\hline PBRC160.OC & $14: 00: 33$ & 12,501 & 11,100 & $-11,21 \%$ & $1.110,00$ & 1,00 \\
\hline PBRC165.AG & $14: 32: 54$ & 3,800 & 3,850 & $+1,32 \%$ & $33.380,00$ & 97,00 \\
\hline PBRC190.AG & $14: 43: 13$ & 0,610 & 0,550 & $-9,84 \%$ & 550,00 & 10,00 \\
\hline PBRV130.AG & $13: 45: 35$ & 1,599 & 1,400 & $-12,45 \%$ & 420,00 & 3,00 \\
\hline PBRV150.AG & $11: 57: 57$ & 7,788 & 7,500 & $-3,70 \%$ & $3.000,00$ & 4,00 \\
\hline PGRC8.00AG & $14: 32: 57$ & 0,490 & 0,350 & $-28,57 \%$ & 35,00 & 1,00 \\
\hline PGRC8.50AG & $11: 55: 53$ & 0,101 & 0,100 & $-0,99 \%$ & $1.500,00$ & 150,00 \\
\hline TECC115.AG & $13: 42: 15$ & 8,000 & 7,000 & $-12,50 \%$ & $22.200,00$ & 29,00 \\
\hline TXAC12.75G & $14: 40: 45$ & 2,600 & 2,000 & $-23,08 \%$ & $81.875,00$ & 385,00 \\
\hline TXAC13.75G & $14: 41: 42$ & 1,226 & 1,000 & $-18,43 \%$ & $37.408,00$ & 357,00 \\
\hline TXAC15.0AG & $13: 59: 56$ & 0,700 & 0,500 & $-28,57 \%$ & $15.958,00$ & 294,00 \\
\hline TXAC16.0AG & $14: 01: 45$ & 0,300 & 0,250 & $-16,67 \%$ & 400,00 & 12,00 \\
\hline TXAC17.0AG & $14: 45: 13$ & 0,100 & 0,070 & $-30,00 \%$ & $1.003,00$ & 124,00 \\
\hline TXAC18.0AG & $12: 16: 23$ & 0,056 & 0,040 & $-28,57 \%$ & 4,00 & 1,00 \\
\hline YPFC48.AG & $13: 16: 25$ & 18,100 & 15,000 & $-17,13 \%$ & $7.500,00$ & $139.800,00$ \\
\hline YPFC500.AG & $14: 23: 12$ & 12,000 & 11,000 & $-8,33 \%$ & 128,00 \\
\hline
\end{tabular}

Out of 76 listed options, only $9(11,8 \%)$ of them are puts (highlighted with yellow and identified by the letter $\mathrm{V}$ as the fourth character). The rare availabity of put options is also limited to some stocks, not to the index (they were written that day on three underlying assets only, \$VALO, \$GGAL, and \$APBR).

There is also no put options on the Mer.Val. index itself, so investors seeking hedge against a downside movement has no place to go, and must rely on the sole chance of guessing and switching to a risk-free asset before any downside movement happens, or to keep some money saved (which in turn is similar to self-insurance).

There is another market in Argentina, called Rofex ${ }^{4}$. Futures on the Mer.Val. index where traded there on the past, but due to the lack of understanding between both exchanges ${ }^{5}$, they had to create their own stock index to uses as an underlying to offer derivatives on it ${ }^{6}$. The equivalent index to the Mer.Val. index, is named the Rofex20, and the exchange quotes derivatives written over it. The following screen capture shows the futures on the Rofex20:

Data 2

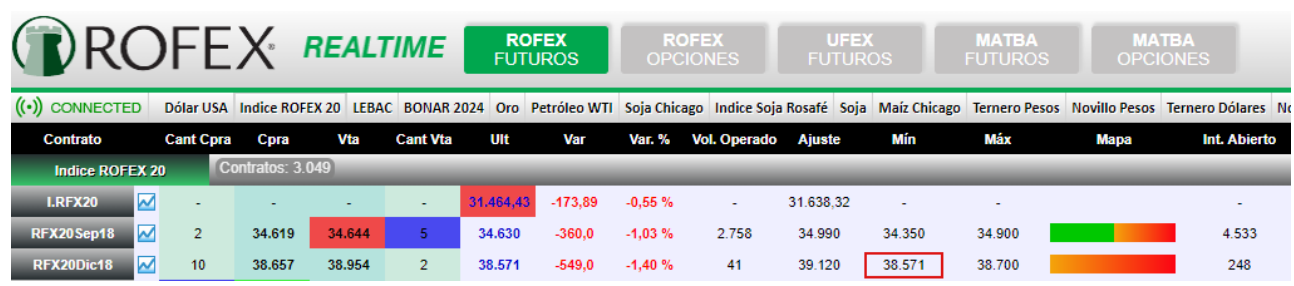

and here we can see the options on the same index:

\footnotetext{
${ }_{5}^{4}$ Rosario Futures Exchange (http://www.rofex.com.ar/).

${ }^{5} \mathrm{http} / / /$ www.ambito.com/909955-cortocircuito-en-el-mercado-byma-decidio-finalizar-vinculo-con-el-rofex ${ }^{6}$ https://www.cronista.com/finanzasmercados/La-CNV-aprobo-el-Rofex20-como-funcionara-el-nuevo-indice-defuturo-de-acciones-20180405-0077.html
} 


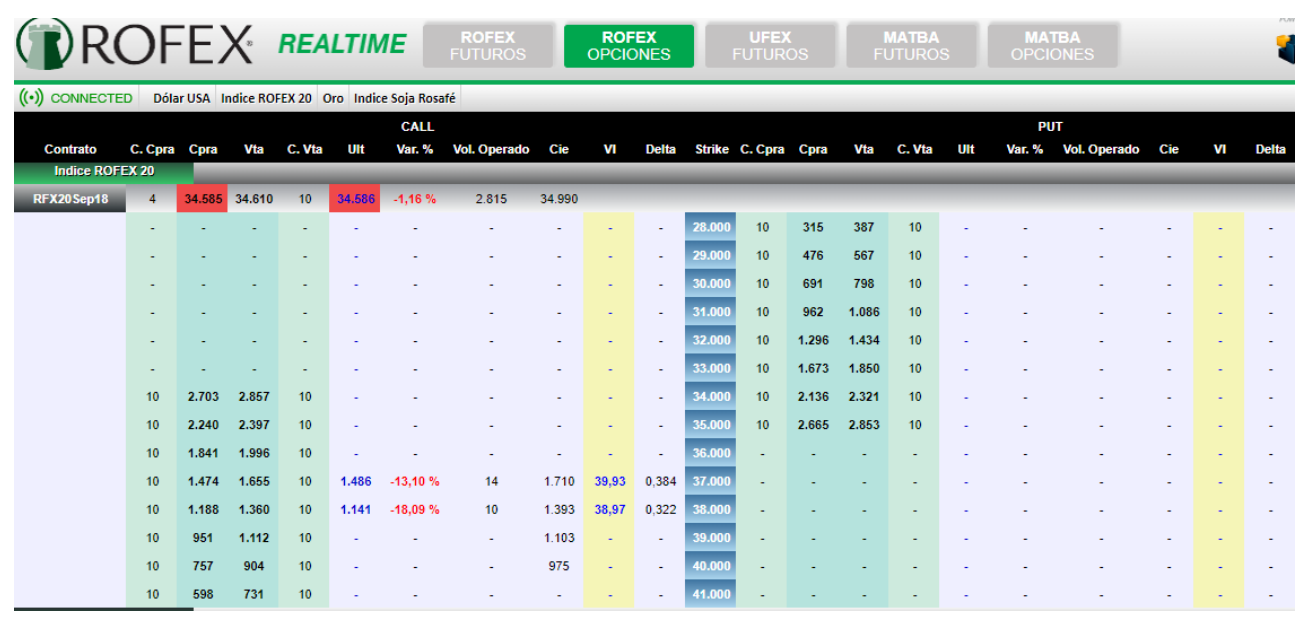

In the futures screen, there were at the time $e^{7}$ only two contracts traded, with maturity September and December, while in the options screen we find pretty much the same situation, few contracts and lack of liquidity and market depth.

Summing up, from empirical data we can appreciate the existence of downside risk in Argentinean stocks, while the offer of proper protection against that risk is almost non-existent ${ }^{8}$, which is far more common in developed markets.

The purpose of this paper is to suggest a framework as a starting point to price the supply of contracts hedging against downside movements in the stocks market, according to an economic situation where the standard pricing mechanisms for options are somehow restricted.

\section{Standard options pricing}

Option contracts are like any other product traded in the economy, they are sold at a price that conform both buyers and sellers, depending on the need and availability. A Nobel Prize in economics was awarded to Merton and Scholes (the third one was Fisher Black who died before being awarded) for deriving a stylized valuation mechanism, constructing on a previous setting from Arrow-Debreu-McKenzie. They proposed a closed formula for the valuation of options, based on the possibility of building a replicating portfolio consisting in a dynamic linear combination of the underlying asset and a risk free asset, where weights are chosen to replicate the payoff of the sought option, and hence facing exactly the same risk, both assets must have the same present value at each time in an arbitrage free environment.

For a non-paying dividends asset, the famous Black Scholes Merton (BSM) formula for a European put is:

$$
p=X e^{-r T} N\left(-d_{2}\right)-S_{0} N\left(-d_{1}\right)
$$

\footnotetext{
${ }^{7}$ On Thursday, 7/19/2018.

${ }^{8}$ Baer (2006) argues that while the volume traded in ROFEX grew at an annual average of $200 \%$ in the period 2003 2007, still far from the relative records of other countries of the region; in 2007 the number of contracts operated per unit of GDP (contracts/GDP) represented in Argentina 22.4\% of contracts / GDP of Brazil and 48.1\% of contracts / GDP of Mexico (the largest organized markets in the region).
} 
where $p$ is the value of the put, $S_{0}$ is the current value of the underlying asset, $X$ is the price at which the buyer has the right to sell, $r$ is the risk-free rate and $T$ is the time to maturity; $N\left(-d_{1}\right)$ and $N\left(-d_{2}\right)$ show the cumulative standardized normal distribution to certain points constructed by the use of the previous parameters.

This is a standard and basic formula for simple option valuation where a risk-adjusted expected rate of return is not needed, because stems from the assumption that investors are risk neutral. However, it requires the existence of complete capital markets where replicating portfolios con be constructed and adjusted cost-free and with high levels of liquidity.

Even though most of the literature focuses on the ex-ante valuation of options, or on how options should be priced, it becomes more difficult to find research comparing the ex-ante value with the ex-post payoffs. In Dapena Siri (2016) we adopted a different approach to evaluate the realized returns of options, from the seller's perspective. We set up a passive investment strategy, selling put and call options in the market, keeping the required margin and paying "claims" when options ended in the money, just like an insurance provider.

We aim to follow a similar approach in this paper. Given the fact that Argentine's capital markets are less developed (specially stock markets ${ }^{9}$ ), the fact that dealing with short selling, liquidity issues and transaction costs require a less sophisticated method, at least at this stance, and that is where our insurance approach may be of help.

This insurance approach means that from an actuarial viewpoint, premiums collected by options, adjusted by the time value of money, must compensate for the claims paid. To clarify, if we were to sell put options on one index, the options at expiration may end in the money, or out/at the money. Should it be the first case, the seller (labelled as the insurance company), must pay at the request of the buyer the difference between the spot price at expiration and the strike or exercise price; on the other hand, should the put option ends up at/out of the money, the seller or insurance company does not pay anything and gets the right to keep any premiums collected.

Given that the possibility of short selling is restricted, we seek to calculate prices resorting to self-insurance, i.e. a firm that invests its own capital to afford the payment of claims. According to that, we seek to calculate what is the minimum price such a firm would charge to provide downside risk hedging in the domestic capital market. That price thus calculated will not include an extra charge for operative expenditure, transaction costs, or risk premium on the capital needed. However, it may be useful as a starting point to start offering such contracts in the domestic market. As we said before, prices are a private matter between buyers and sellers, and at an appropriate price we can find both parties, so we stand from the side of the seller in the real domestic capital market.

With that in mind, our research covers a timespan of more than fifteen years (from 2003 to 2018) and evaluates how much money a seller that systematically offers at-the-money european put options on the Mer.Val. index must keep to afford the in-the-money events realized. We therefore calculate the minimum actuarially fair price (not including operative expenses, transaction costs or risk premium) that must be charged to end up even.

\footnotetext{
${ }^{9}$ See Dapena (2007).
} 


\section{Model to be developed}

\section{a. Data and methodology}

Our proposition is to study the realized returns of synthetic put options on the Mer.Val. index for a long period of time. Under the assumption they are kept until expiration -denominated as a passive investment strategy-, we evaluate the results of such a strategy in terms of the insurance company example mentioned before. The calculation allows us to obtain a loss function from the payments effectively faced at each contract's expiration date -in the case the option ends up in the money-, and from that loss function to calculate a minimum accumulated capital requirement needed by an option seller.

Loss function: $\sum_{t=0}^{T}(X-S) *(1+r f)^{t}$ for all $X>S$

If seen from the perspective of an insurance company which collects policy premiums, selling a put insures against a downward movement of the market works in a similar fashion. In the analogy with car insurance, just as most drivers do not have accidents, many (and perhaps most) of the option sellers will never end up facing their obligations. However, as in insurance industry, a few bad accidents can hurt the P\&L. Therefore, an insurance company tries to reduce the likelihood that insured drivers will have an accident by checking a number of factors such as driving record, age of the drivers, type of cars, etc. An option seller goes through the same process, but instead of studying drivers' behaviour, she may study the market's "driving record" which is shown by historical tendencies, current and future economic fundamentals, etc.

The period of time for the present paper spans between January $3^{\text {rd }}, 2003$ and June $29^{\text {th }}, 2018$. The price history for the Mer.Val. index is retrieved from Thomson Reuters Eikon. As for the risk-free rate, we use effective rate derived from short-term LEBAC instruments (Argentine Central Bank's Letters of Credit).

As for the methodological procedure, it operates in the following way:

- Every single trading day since inception, we write a synthetic European at-themoney (ATM) put option on the index with a fixed maturity of 21 trading days.

- At maturity we evaluate the payoff function. If it happens to be in the money, we calculate the amount to be paid and accumulates it into a loss function.

- the loss account carries interest at the denominated risk-free rate.

- At the end of the experiment, we set the average price of the put option as a percentage of the Mer.Val. index, as to offset the accumulated loss account. That gives us the minimum actuarially fair price of the put under this approach.

We acknowledge the results are path dependent, both on the index performance as well as the risk-free rate level, but they should offset each other, as a rising interest rate should impact 
positively on the drift term of the risky asset (based on the notion that risk should be rewarded with a positive spread when comparing assets involving different levels of risk).

\section{b. Results}

After running the procedure for the whole sample, one can draw several numerical insights from systematically selling ATM put options. First, $60 \%$ of the options written on the index end up expiring worthless. Second, the statistics for the whole options payoff sample, as well as conditional on ending up at-the-money, are:

\section{Graph 3. Historical put options payoff at expiration}

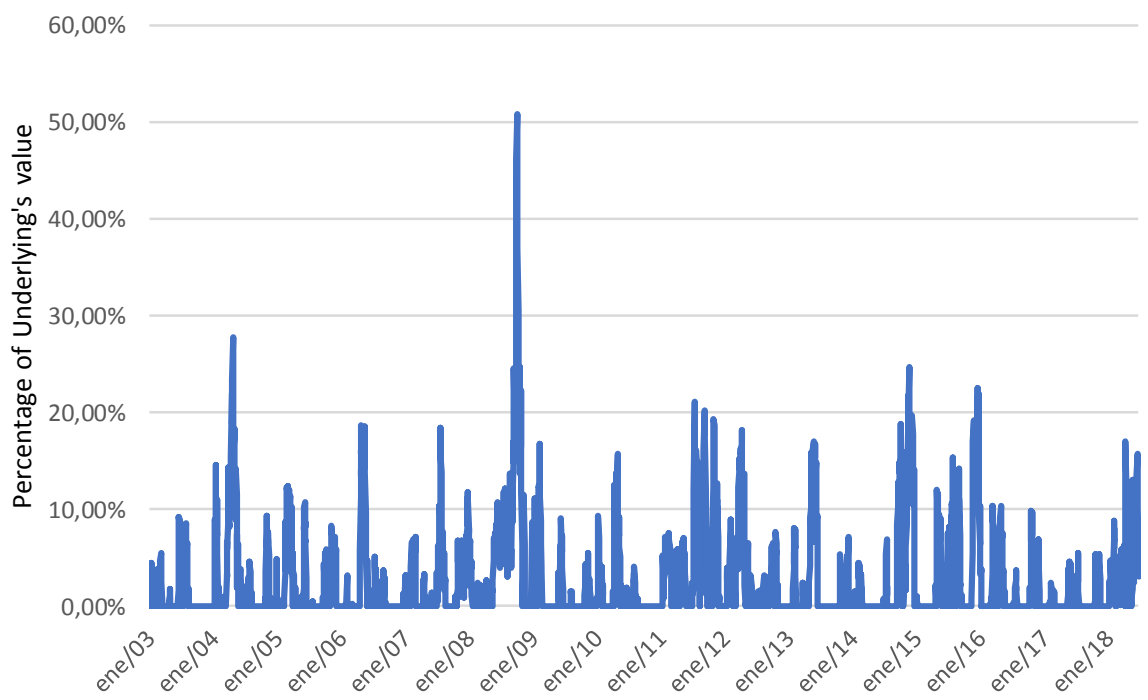

Table 2. Descriptive Statistics for Loss Function

\begin{tabular}{|l|r|}
\hline Average & $-2,50 \%$ \\
\hline S.D. & $4,79 \%$ \\
\hline Max & $-50,83 \%$ \\
\hline Min & $0,00 \%$ \\
\hline$\%$ of ATM & $39,96 \%$ \\
\hline Total Obs. \\
\hline \multicolumn{2}{|c|}{ Condition ATM options } \\
\hline Average & $-6,25 \%$ \\
\hline Median & $-4,79 \%$ \\
\hline S.D. & $5,83 \%$ \\
\hline
\end{tabular}

Third, once filtered for worthless payoffs, the average loss on selling put options more than doubles, from $2,50 \%$ to $6,25 \%$ (as a percentage of the underlying index's value at the time the options are written). And fourth, given the index is denominated in Argentinean Pesos (ARS), the loss function accumulates a total of more than 1.6 million ARS for the whole sample. Of that amount, less then $34 \%$ is attributed to the money being paid at options expiration, while the rest if just interest paid on the balance carried forward. It can be appreciated in Graph 4, the red 
line is the accumulated loss for the pure options' payoffs while the blue line is that balance compounded at the risk-free rate.

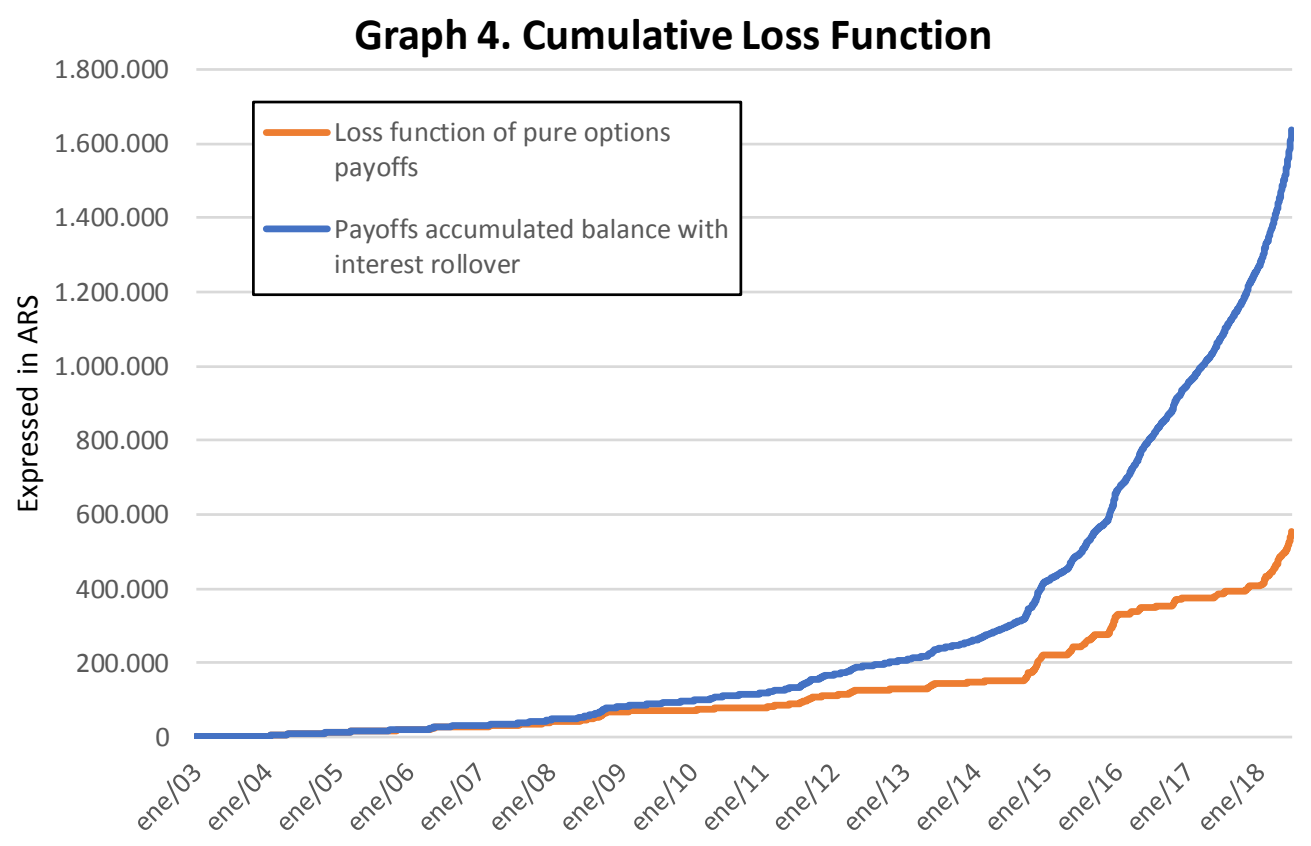

We can now move forward to calculating the required average value (as a percentage of the index) that put options should have had as a premium, in order to offset the accumulated loss. For the referred calculation, one must set up a value for the option such that all the premiums collected and compounded at the risk-free rate end up having a terminal value equivalent to the aforementioned cumulative loss function. The average premium stands at roughly 2,63\%, meaning that a put option written on the Mer.Val. index, at any given moment in time, should at least be written for 2,63\% of the underlying asset's value. When facing the restriction that the money collected as premiums cannot be compounded (at any interest rate), then the average value of ATM put options should be at least 7,18\%, conditional on the index path for the given sample.

\section{c. Application of the Black-Sholes-Merton formula}

Thinking in a different way, we could try to value the options through an options pricing model. We will use the Black-Scholes-Merton (BSM) put option formula to calculate a premium at 21, 63 and 252 trading days realized volatilities. The following graph shows the progress for different time frame realized volatility of the index. The table below it displays the average realized volatility as well as the average ATM put option price when applying each volatility. 


\section{Graph 5. Realized Volatility for 21, 63 and 252 trading \\ days}

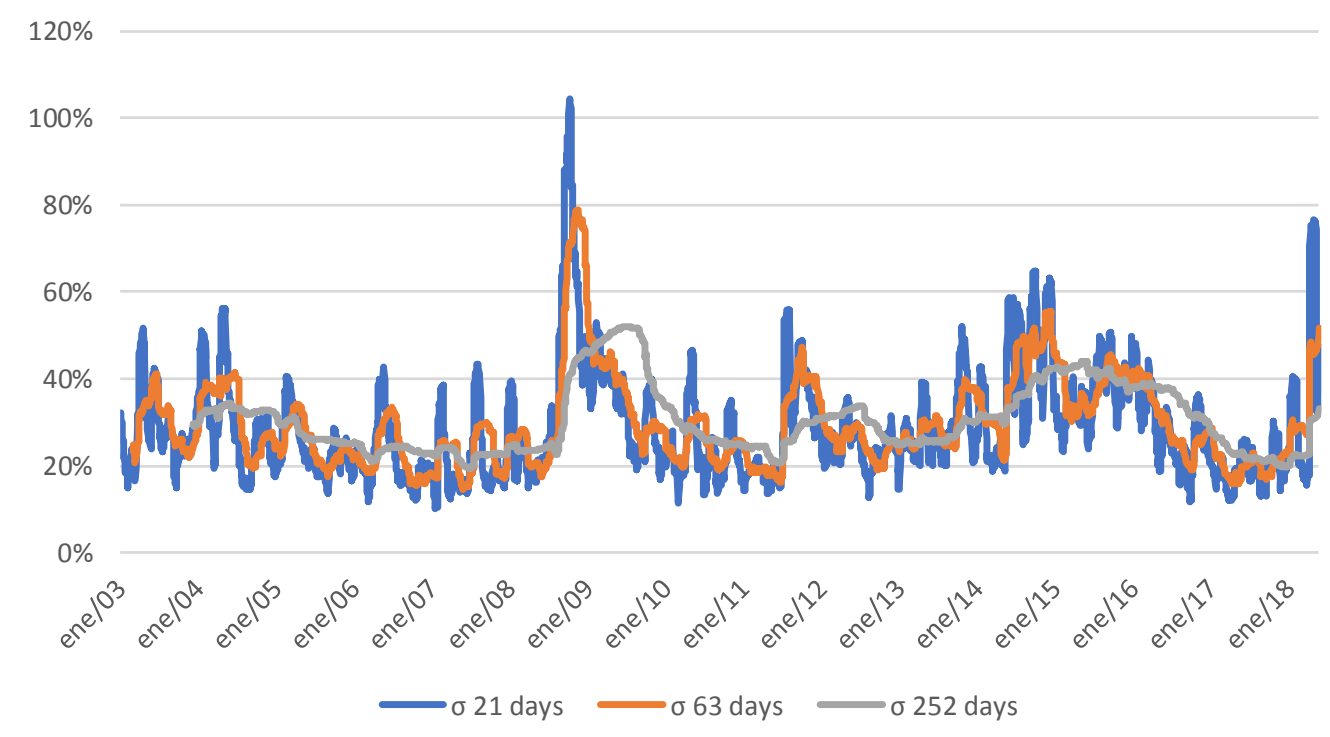

\begin{tabular}{|l|r|r|r|}
\cline { 2 - 4 } \multicolumn{1}{c|}{} & \multicolumn{3}{c|}{ Realized Volatility $(\boldsymbol{\sigma})$} \\
\cline { 2 - 4 } \multicolumn{1}{c|}{} & $\mathbf{2 1}$ days & $\mathbf{6 3}$ days & \multicolumn{1}{c|}{$\mathbf{2 5 2}$ days } \\
\hline Average level & $28,73 \%$ & $29,53 \%$ & $30,32 \%$ \\
\hline Average put option price & $2,70 \%$ & $2,79 \%$ & $2,86 \%$ \\
\hline
\end{tabular}

We can appreciate that the average price for the puts, when valued through the BSM model aren't far away from the loss-function approach.

\section{Conclusions}

No one can deny the fact that it has become much easier to perform calculation with data gathering and data processing. In this paper we show a simple case where instead of resorting to a world of theoretical assumptions to calculate the value of an option contract, instead we use historic data, algorithms and knowledge to obtain the price. The availability of data and the processing power allows us to proceed and calculate option pricing in a way that were difficult to imagine in the past. The local capital market, its indices and constituents are risky but at the same time they offer almost no downside protection to mitigate such risks. One can argue that investors do not need the protection, statement which proves false even for well-diversified portfolios. The fact that capital markets in Argentina lack both depth and liquidity, short selling is somehow restricted and scarce in practical terms, together with high transaction costs makes hedging challenging. We give through this paper a different perspective for offering insurance in the local market. In our approach, sellers bear the risk and, under the assumption they lack the necessary capital to face the payoffs, meaning they incur in loans to develop such a business, we show the minimum required value of the options. With that in mind, based on historical results, 
one can argue in favour of a risk premium charged for offering downside protection. Given the fact almost no one has infinite access to a lending facility and as this procedure carries risk, one would think a spread must be priced into the premiums charged in order to find an equilibrium were market participants would be willing to face the risk. Nevertheless, the logic driving the process outlined here still stands.

\section{References}

Arrow, K. J. and Debreu, G. (1954), "Existence of an equilibrium for a competitive economy". Econometrica 22 (3): 265-290

Baer, Fernando (2006). "Mercado de Futuros y Derivados en Argentina". Documento de Trabajo No 15. Centro para la Estabilidad Financiera. Buenos Aires. Argentina.

Black F., and Scholes M. (1973), "The Pricing of Options y Corporate Liabilities". Journal of Political Economy 81 (May-June): 637-659

Bry, G., and Boschan, C. (1971), "Cyclical Analysis of Time Series: Selected Procedures and Computer Programs”. NBER: New York.

Chauvet, M., and Potter, S. (2000), "Coincident and leading indicators of the stock market". Journal of Empirical Finance 7: 87-111

Cordier J. y Gross M., (2009). The Complete Guide to Option Selling. Mc Graw Hill.

Cox J., Ross, S., and Rubinstein M. (1979), “Option pricing: A simplified approach”. Journal of Financial Economics 7, no. 3:229-263

Dapena J.P. (2014). "A short note on expected risk adjusted elasticity and consumer theory". Universidad del CEMA Doc de trabajo 558

Dapena J.P. (2009). "Rol del mercado de capitales en el crecimiento de la economía: literatura y evidencia para Argentina". Universidad del CEMA Doc de trabajo 393

Dapena J.P. (2006). "Volatility of GDP, macro applications and policy implications of real options for structure of capital Markets". Universidad del CEMA Doc de trabajo 320

Dapena J.P and Siri J. (2016 En curso). "Testing Excess Returns from Passive Options Investment Strategies". Universidad del CEMA Doc de trabajo en curso

Dapena J.P and Siri J. (2015). "Index Options Realized Returns distributions from Passive Investment Strategies”. Universidad del CEMA Doc de trabajo 580.

Gonzalez, L.; Powell, J. G.; Shi, J., and Wilson, A. (2004), "Two centuries of bull and bear market cycles". International Review of Economics and Finance 14 (2005): 469-486

Haug E. and Taleb N., Option Traders use (very) sophisticated Heuristics, never the BlackScholes-Merton Formula, SSRN 1012075 (2010). 
Hull J., (1993). Options, Futures and other Derivative Securities. Prentice Hall. Second Ed.

Ilmanen A. (2012). "Do Financial Markets reward Buying or Selling Insurance and Lottery Tickets?”. Financial Analysts Journal, Vol 68 No. 5

Kim, C. J., and Nelson, C. R. (1999). State-Space Models with Regime Switching. The MIT Press.

McKenzie, Lionel W. (1959). "On the Existence of General Equilibrium for a Competitive Economy". Econometrica 27 (1): 54-71

Merton R. C. (1973), "Theory of Rational Option Pricing”. Bell Journal of Economics y Management Science 4, no. 1: 141-183

Pagan, A. R., and Sossounov, K. A. (2003), “A Simple Framework for Analysing Bull and Bear Markets”. Journal of Applied Econometrics, Vol 18, No. 1 (Jan. - Feb.): 23-46

OCC Rules, Option Clearing Company, 2014.

Siri J. and Dapena J.P (2014). "Comparación entre algoritmos de Ciclos y Modelos de RegimeSwitching con aplicación a Estrategias de Inversión". Universidad del CEMA Doc de trabajo 540 . 